\title{
Efficiency of nitrogen usage in maize cultivars for grain production
}

\section{Eficiência de utilização de nitrogênio por cultivares de milho para produção grãos}

\section{Cassiana Felipe de SOUSA ${ }^{1}$; Leilson Costa GRANGEIRO²; Valdivia de Fátima Lima de SOUSA ${ }^{3}$; Jader Vieira CARNEIRO ${ }^{4}$; Gardênia Silvana de Oliveira RODRIGUES ${ }^{5}$}

${ }^{1}$ Doutora em Fitotecnia - Agronomia, cassianafelipe@gmail.com

${ }^{2}$ Autor para correspondência" Doutor em Produção Vegetal - Agronomia, Universidade Federal Rural do Semi-Árido, leilson@ufersa.edu.br

${ }^{3}$ Doutora em Fitotecnia - Agronomia, Agrícola Famosa, valdivia_sousa@hotmail.com

${ }^{4}$ Mestre em Química e Fertilidade de solo - Agronomia, jadder_19@hotmail.com

${ }^{5}$ Doutora em Fitotecnia - Agronomia, Universidade Federal Rural do Semi-Árido, gardeniavg@yahoo.com.br

Recebido em: 20-04-2020; Aceito em: 04-05-2020

\begin{abstract}
Maize plays an important role in the economy and the social and cultural development of several regions in Brazil. However, its productivity is considered low, since the management of nitrogen fertilization and the selection of efficient cultivars in using nitrogen are the main factors responsible for the low productivity of this crop. This study had the purpose to evaluate the efficiency of nitrogen usage in maize cultivars for the production of grains. The experiment was conducted at the vegetable garden at Universidade Federal Rural do Semi-Árido, in the municipality of Mossoró - Rio Grande do Norte state, Brazil. Treatments consisted in the combination of two nitrogen doses ( 0 and $90 \mathrm{~kg} \mathrm{~N} \mathrm{ha}^{-1}$ ) and three maize cultivars (Cruzeta, Truck and AG 1051). A randomized complete block experimental design was used, in a $2 \times 3$ factorial arrangement, with five replications. The most productive performance was observed when the evaluated cultivars were fertilized with nitrogen. Based on the values from nutritional indices, cultivar AG 1051 was more efficient in using nitrogen to produce grains.
\end{abstract}

Additional keywords: mineral nutrition; nutritional efficiency indices; yield; Zea mays.

\section{Resumo}

O milho possui importante papel na economia e desenvolvimento social e cultural de várias regiões do Brasil. No entanto, a produtividade é considerada baixa, sendo o manejo da adubação nitrogenada e a seleção de cultivares eficientes no uso do nitrogênio os principais fatores responsáveis pela baixa produtividade desta cultura. $O$ presente trabalho teve como objetivo avaliar a eficiência de utilização de nitrogênio por cultivares de milho, para produção de grãos. O experimento foi realizado na Universidade Federal Rural do Semi-Árido, no município de Mossoró-RN. Os tratamentos foram constituídos pela combinação de duas doses de nitrogênio (0 e $90 \mathrm{~kg} \mathrm{ha}^{-1} \mathrm{de}$ N) e três cultivares de milho (Cruzeta, Truck e AG 1051). O delineamento experimental utilizado foi o de blocos casualizados em esquema fatorial $2 \times 3$, com cinco repetições. O maior desempenho produtivo foi observado quando as cultivares avaliadas foram adubadas com nitrogênio. Com base nos valores dos índices de eficiência nutricional, a cultivar AG 1051 foi mais eficiente na utilização de nitrogênio para a produção de grãos.

Palavras-chave adicionais: índices de eficiência nutricional; nutrição mineral; produtividade; Zea mays.

\section{Introduction}

The world's largest producer of maize is the United States, with an estimated production of approximately 347.78 million tons, followed by China, with an estimated production of 260 million tons, and Brazil, which ranks third with 101.9 million tons. In Brazil, with a cultivated area of 18.2 million hectares, maize occupies the largest cultivated area in the country, and stands out as the greatest produced grain, accounting for the second greatest production value, and being exceeded only by soybeans (CONAB, 2020).

However, the average maize productivity in the country is considered low $\left(5,599 \mathrm{~kg} \mathrm{ha}^{-1}\right)$; in the Northeast, the average productivity is even lower $\left(2,538 \mathrm{~kg} \mathrm{ha}^{-1}\right)$, and in Rio Grande do Norte state this productivity is only $567 \mathrm{~kg} \mathrm{ha}^{-1}$ (ABIMILHO, 2020). However, Rio Grande do Norte has areas with potential for the exploitation of this culture, since it stands out as one of the most important cultures for the region.

Low crop productivity is due to the fact that $43 \%$ of the area cultivated with this grain in the country is for subsistence, that is, farmers use low technology, whereas only $11 \%$ of the farmers use high technology for production (Okumura et al., 2011).

The availability of nitrogen in the soil influences the productivity of maize grains during the entire development cycle of the plant. This is due to its significance in the metabolism of plants, with reflections in productivity, given that the culture demands, on an average, $23.8 \mathrm{~kg}$ of $\mathrm{N}$ per grain ton (Schiavinatti et al., 2011; Caires \& Milla, 2016). However, the inadequate 
supply of nitrogen can cause a limitation in maize productivity, as well as causing environmental contamination and raising costs.

Also, it is worth highlighting the use of cultivars with limited production potential and/or not adapted to a particular production environment, deficiencies in the availability and use of nutrients, especially $\mathrm{N}$, and of water during the development cycle of the culture, poor control of pest-insects, diseases and weeds (Oliveira et al., 2016).

On the other hand, high maize yields can be guaranteed by adapting cultivars to the most varied climatic and soil conditions, by genetic improvement, by improving the chemical, physical and biological properties of cultivated soils, as well as by adopting cultural practices, such as the use of fertilizers, especially nitrogen (Okumura et al., 2011).

The identification of genotypes that have the capacity to absorb and use nitrogen efficiently is also a way to increase the use efficiency of nitrogen fertilization in maize, to increase production, minimize losses and reduce the contamination of the environment (Santos et al., 2017).

Considering the aforementioned, the purpose of this work was to evaluate the efficiency of nitrogen usage in maize cultivars for the production of grains.

\section{Material and methods}

\section{Site Location and Characterization}

The experiment was conducted at Universidade Federal Rural do Semi-Árido, in the municipality of Mossoró - Rio Grande do Norte state (5'11"S, $37^{\circ} 20^{\prime \prime} \mathrm{W}$ and $18 \mathrm{~m}$ a.s.I). The climate of the region, according to Thornthwaite, is semi-arid, and according to Köeppen's classification, it is BSwh type, hot and dry, with an annual average rainfall of $673.9 \mathrm{~mm}$, mean temperature of $27^{\circ} \mathrm{C}$ and relative humidity of $68.9 \%$, with two climatic seasons: a dry season, usually from June to January, and a rainy season, from February to May (Alvares et al., 2013).

The soil of the experimental area was classified as Eutrophic Red-Yellow Argisol (Rego et al., 2016). The chemical analysis performed in soil samples from the experimental area, at depth between 0 and $20 \mathrm{~cm}$, showed the following results: $\mathrm{pH}\left(\mathrm{H}_{2} \mathrm{O}\right)=7.5 ; \mathrm{P}$ (mehlich1) $=210.83 \mathrm{mg} \mathrm{dm}{ }^{-3} ; \mathrm{K}=205.40 \mathrm{mg} \mathrm{dm}^{-3} ; \mathrm{Ca}=$ $3.09 \mathrm{cmol}_{\mathrm{c}} \mathrm{dm}^{-3} ; \mathrm{Mg}=1.26 \mathrm{cmol}_{\mathrm{c}} \mathrm{dm}^{-3} ; \mathrm{Al}=$ $0.10 \mathrm{cmol}_{\mathrm{c}} \mathrm{dm}^{-3} ; \mathrm{H}+\mathrm{Al}=1.0 \mathrm{cmol}_{\mathrm{c}} \mathrm{dm}^{-3} ;$ Organic matter $=12.8 \mathrm{~g} \mathrm{~kg}^{-1}$.

\section{Treatments and Experimental Design}

Treatments consisted in the combination of two nitrogen doses ( 0 and $90 \mathrm{~kg} \mathrm{ha}^{-1}$ ) and three maize cultivars (Cruzeta, Truck and AG 1051). A randomized complete block experimental design was used, in a $2 \times 3$ factorial arrangement, with five replications. Each experimental plot was composed by three rows measuring $3 \mathrm{~m}$ in length, spaced $0.8 \mathrm{~m}$ apart, containing 10 plants in each row. The central row was considered as the useful area, discarding a plant at each end.
The two nitrogen doses were used to evaluate the efficiency of $\mathrm{N}$ usage in maize cultivars, where the "0" dose corresponded to the $\mathrm{N}$ content of the soil $\left(\mathrm{D}_{0}\right)$, and the $90 \mathrm{~kg} \mathrm{ha}^{-1}$ dose (D90) was the recommended one for maize, according to Cavalcanti (2008). Maize cultivars were selected among the ones used in the region, namely Cruzeta (open pollinated cultivar), Truck (modified triple hybrid) and AG 1051 (double hybrid).

\section{Field Establishment}

Soil was prepared through plowing and harrowing, followed by making furrows with a depth of approximately $0.20 \mathrm{~m}$ for planting fertilization, based on soil analysis and recommendation of Cavalcanti (2008), using: $30 \mathrm{~kg} \mathrm{ha}^{-1}$ of $\mathrm{N}$ (part of the $\mathrm{N}$ treatment); $40 \mathrm{~kg} \mathrm{ha}^{-1}$ of $\mathrm{P}_{2} \mathrm{O}_{5}, 40 \mathrm{~kg} \mathrm{ha}{ }^{-1}$ of $\mathrm{K}_{2} \mathrm{O} ; 1.0 \mathrm{~kg} \mathrm{ha}^{-1}$ of $\mathrm{B}$ and $3.0 \mathrm{~kg} \mathrm{ha}{ }^{-1}$ of $\mathrm{Zn}$. In the $\mathrm{N}$ treatment top-dressing, $30 \mathrm{~kg} \mathrm{ha}^{-1}$ of $\mathrm{N}$ were applied 15 days after sowing (DAS) and $30 \mathrm{~kg} \mathrm{ha}^{-1}$ of $\mathrm{N}$ were applied when plants presented eight final leaves. The used sources were urea, triple superphosphate, potassium chloride, boric acid and zinc sulfate.

Sowing was carried out with three seeds per pit, in the spacing of $0.8 \mathrm{~m} \times 0.3 \mathrm{~m}$ and, when plants had four definitive leaves (9 DAS), thinning was performed, leaving one plant per pit. Drip irrigation was performed, with emitters spaced $0.3 \mathrm{~m}$ apart and flow of $1.4 \mathrm{~L} \mathrm{~h}^{-1}$. Weed control, when necessary, was accomplished through manual weeding. Four sprayings were performed, using the insecticides Decis® $\left(200 \mathrm{~mL} \mathrm{ha}^{-1}\right)$ and Premioß $\left(100 \mathrm{~mL} \mathrm{ha}^{-1}\right)$, in order to control fall armyworms (Spodoptera frugiperda J. E. Smith).

\section{Harvesting and Parameters Evaluated}

Harvesting was carried out manually at the R6 phenological stage (physiological maturity), 113 days after sowing (DAS). Two plants per plot were cut in the base region, separated in leaves, stem and cob, washed and dried in a forced air circulation oven (65 ${ }^{\circ} \mathrm{C}$ ) until reaching constant weight, to obtain the dry mass of the plant. After that, the $\mathrm{N}$ content of the aforementioned parts was determined.

The productivity was obtained from the threshing and weighing of grains from ears harvested in the useful area of the plots, which was converted to $\mathrm{kg}$ ha $^{-1}$ and corrected to $15.5 \%$ moisture content.

$\mathrm{N}$ accumulation values were obtained by the product between $\mathrm{N}$ content and dry mass. With data about dry mass and $\mathrm{N}$ accumulation, the following indices were calculated, according to Fageria et al. (2007): Agronomic efficiency (AE); Physiological efficiency (PE); Grain production efficiency (GPE); Recovery efficiency (RE) and Usage efficiency (UE), using the following equations:

$$
\begin{aligned}
& \mathrm{AE}\left(\mathrm{kg} \mathrm{kg}^{-1}\right)=\left(P \mathrm{G}_{\mathrm{N}}-\mathrm{PG} \mathrm{G}_{\mathrm{w}}\right) /\left(\mathrm{QN}_{\mathrm{a}}\right) \\
& \mathrm{PE}\left(\mathrm{kg} \mathrm{kg}^{-1}\right)=\left(\mathrm{TDM}_{\mathrm{N}}-\mathrm{TD}_{\mathrm{wN}}\right) /\left(\mathrm{AN}_{\mathrm{N}}-\mathrm{AN}_{\mathrm{wN}}\right) \\
& \operatorname{GPE}\left(\mathrm{kg} \mathrm{kg}^{-1}\right)=\left(P \mathrm{G}_{N}-\mathrm{PG}_{\mathrm{wN}}\right) /\left(\mathrm{ANN}_{\mathrm{N}}-\mathrm{AN}_{\mathrm{wN}}\right) \\
& \operatorname{RE}\left(\mathrm{kg} \mathrm{kg}^{-1}\right)=\left(\mathrm{ANN}_{\mathrm{N}}-\mathrm{AN} \mathrm{wN}_{\mathrm{N}}\right) /\left(\mathrm{QN}_{\mathrm{a}}\right)
\end{aligned}
$$




$$
\mathrm{EU}\left(\mathrm{kg} \mathrm{kg}^{-1}\right)=\mathrm{PE} \times \mathrm{RE}
$$

Wherein: $P G_{N}$ is the production of grains with nitrogen fertilization $(\mathrm{kg})$; $P G_{w N}$ is the production of grains without nitrogen fertilization $(\mathrm{kg}) ; \mathrm{QN}_{\mathrm{a}}$ is the quantity of applied $\mathrm{N}(\mathrm{kg}) ; \mathrm{TDM}_{\mathrm{N}}$ is the production of total dry mass with nitrogen fertilization $(\mathrm{kg})$; $\mathrm{TDM}_{\mathrm{wN}}$ is the production of total dry mass without nitrogen fertilization $(\mathrm{kg})$; $A N_{N}$ is the total $\mathrm{N}$ accumulation with nitrogen fertilization $(\mathrm{kg})$ and $A N_{w N}$ is the total $\mathrm{N}$ accumulation without nitrogen fertilization $(\mathrm{kg})$.

\section{Statistical Analysis}

Data were submitted to analysis of variance and the means were compared by Tukey's test, at 5\% probability, using the statistical program SISVAR (Ferreira, 2014).

\section{Results and discussion}

There was no significant interaction for any of the studied variables. However, for the variables plant dry mass, potassium $(\mathrm{K})$ accumulation and productivity, the individual factors ( $\mathrm{N}$ doses and cultivar) were significant, whereas for the accumulation of nitrogen $(\mathrm{N})$ and phosphorus $(P)$, the sole dose factor was significant.

Cultivars differed as for plant dry mass and potassium accumulation. 'Cruzeta', as well as 'Truck', presented the greatest plant dry mass and the greatest potassium accumulations (Table 1).

Table 1 - Total dry mass (TDM), accumulations of nitrogen $(\mathrm{N})$, phosphorus $(\mathrm{P})$ and potassium $(\mathrm{K})$ and grain productivity (PROD) according to corn cultivar and $\mathrm{N}$ dose.

\begin{tabular}{lccccc}
\hline Cultivars & TDM & $\mathrm{N}$ & $\mathrm{P}$ & $\mathrm{K}$ & PROD \\
\hline Cruzeta & $159.86 \mathrm{a}$ & $2.02 \mathrm{a}$ & $0.47 \mathrm{a}$ & $3.36 \mathrm{a}$ & $4116.89 \mathrm{a}$ \\
TrucK & $140.80 \mathrm{a}$ & $1.80 \mathrm{a}$ & $0.37 \mathrm{a}$ & $3.08 \mathrm{ab}$ & $3724.71 \mathrm{a}$ \\
AG 1051 & $134.42 \mathrm{~b}$ & $1.84 \mathrm{a}$ & $0.44 \mathrm{a}$ & $2.63 \mathrm{~b}$ & $4328.88 \mathrm{a}$ \\
\hline N Dose $\left(\mathrm{kg} \mathrm{ha}^{-1}\right)$ & & & & & \\
\hline 0 & $126.25 \mathrm{~b}$ & $1.49 \mathrm{~b}$ & $0.36 \mathrm{~b}$ & $2.56 \mathrm{~b}$ & $3625.69 \mathrm{~b}$ \\
90 & $163.38 \mathrm{a}$ & $2.29 \mathrm{a}$ & $0.50 \mathrm{a}$ & $3.45 \mathrm{a}$ & $4528.25 \mathrm{a}$ \\
\hline
\end{tabular}

Means followed by the same lowercase letter in the column, within each evaluated factor do not differ by Tukey test at $5 \%$ of probability.

The application of $\mathrm{N}$ provided higher plant dry mass and higher accumulations of $\mathrm{N}, \mathrm{P}$ and $\mathrm{K}$. It is possible to observe a $29.4 \%$ increase in the dry mass of the plant and a $54 ; 37.5$ and $35 \%$ one for $\mathrm{N}, \mathrm{P}$ and $\mathrm{K}$ accumulations, respectively, confirming that the use of $\mathrm{N}$ fertilization may be a primary factor to achieve high yields (Table 2). Carvalho et al. (2011a), while evaluating maize cultivars as for the efficiency of $\mathrm{N}$ absorption and use at two contrasting $\mathrm{N}$ doses, obtained $12.6 \%$ dry mass differences with the application of nitrogen to the soil.

The importance of $\mathrm{N}$ concentration is correlated with grain productivity, where plants with higher $\mathrm{N}$ doses become more proper to allocate carbohydrates to the root system, making it more complete and able to better use the available $\mathrm{N}$, be it from soil or from a fertilizer (Meira et al., 2009).

In addition, it reflects the amount of protein, which is important to estimate the exported $\mathrm{N}$ from maize crops that are intended for whole plant silage or for grain harvest only (Farinelli \& Lemos, 2010; Carvalho et al., 2011b). According to Meira et al. (2009), the amount of $\mathrm{N}$ to be drained to the grain is directly related to the nutritional status of plants, and it also depends on the cycle, the grain filling period and, mainly, on the cultivar.

Grain yield did not differ among the cultivars (Table 2). This result differs from the one found in literature, since hybrids are generally superior to the varie- ties (Carvalho et al., 2011b). However, this response may be attributed to the good production stability and environmental adaptability of the Cruzeta variety.

The addition of nitrogen to the soil provided a $25 \%$ increase in grain productivity (Table 2). This productivity increase was also observed by Ferreira et al. (2009), who relate this fact to the better distribution of $\mathrm{N}$ and its transfer to grains. Carvalho et al. (2011a) also showed that the highest productivity was achieved in the highest dose of $\mathrm{N}$, regardless of the type of material evaluated (single, triple, double or variety hybrid).

Cancellier et al. (2011), while evaluating the $N$ use efficiency and the phenotypic correlation of 24 maize populations in the Southern region of the State of Tocantins, also observed higher yields in environments with high $\mathrm{N}$ dose; an environment with low $\mathrm{N}$ was $23 \%$ less productive. Santos et al. (2017) and Santos et al. (2018) also verified higher grain productivity in environments where the highest $\mathrm{N}$ dose was used. Similar results were also found by Soratto et al. (2011), where grain productivity was influenced by $\mathrm{N}$ doses, and the application of increasing doses of $\mathrm{N}$ in covering provided a quadratic increase in the values of this variable, up to the estimated dose of $124 \mathrm{~kg} \mathrm{ha}^{-1}$, with an increase around $56.8 \%$, in relation to the control treatment, without the application of $\mathrm{N}$ in covering.

It was possible to observe that with a grain yield of $3,625.69 \mathrm{~kg} \mathrm{ha}^{-1}$ (Table 2), in the environment with low $\mathrm{N}$ level (Dose 0 ), the productivity reached in this 
study exceeded the average of Rio Grande do Norte estimated for 2019/2020 harvest, which was $567 \mathrm{~kg} \mathrm{ha}^{-1}$ (ABIMILHO, 2020). This may be due soil characteristics of the experimental area and crop management during the conduct of the experiment

Among the evaluated efficiency indices, there was a significant difference among the cultivars, as for agronomic, grain yield and recovery efficiency.

'AG 1051' presented the highest agronomic $(\mathrm{AE})$ and grain productivity (GPE) efficiency; it did not differ significantly from the cultivar Cruzeta as for GPE
(Table 2). In the AE, for every $14.40 \mathrm{~kg}$ of $\mathrm{N}$ applied to the soil, 'AG 1051' produced $14.40 \mathrm{~kg}$ of grains and in the GPE, for every accumulated N kg, 'AG 1051' was able to produce $48.23 \mathrm{~kg}$ of grains.

This demonstrates that cultivar AG 1051 manages to channel $\mathrm{N}$ more efficiently for the production of maize grains.

Santos et al. (2017) verified genetic variability among 32 maize genotypes regarding the efficiency of use of $\mathrm{N}$.

Table 2 - Agronomic efficiency (AE), physiological efficiency (PE), grain production efficiency (GPE), recovery efficiency (RE) and $\mathrm{N}$ use efficiency (UE) of corn cultivars for the production of grain.

\begin{tabular}{lccccc}
\hline Cultivars & AE & PE & GPE & RE & UE \\
\hline & $-2.0-10$ & $40.30 \mathrm{a}$ & $25.49 \mathrm{~b}$ & $0.51 \mathrm{a}$ & $20.32 \mathrm{a}$ \\
Cruzeta & $12.20 \mathrm{ab}$ & $66.16 \mathrm{a}$ & $22.17 \mathrm{~b}$ & $0.35 \mathrm{ab}$ & $23.27 \mathrm{a}$ \\
Truck & $6.74 \mathrm{~b}$ & $40.77 \mathrm{a}$ & $48.23 \mathrm{a}$ & $0.20 \mathrm{~b}$ & $7.60 \mathrm{a}$ \\
\hline
\end{tabular}

Means followed by the same lowercase letter in the column do not differ by Tukey test at $5 \%$ of probability.

$\mathrm{AE}$ is reflected in a greater economic efficiency in using $\mathrm{N}$, and the production costs can be reduced due to fertilization management. However, AE may decrease according to the increase in the applied $\mathrm{N}$ doses, in case $\mathrm{N}$ supply exceeds crop requirements (Andrade et al., 2014). This is due to the fact that not always the recommended amount to obtain high yields, which generally exceeds the $120 \mathrm{~kg} \mathrm{ha}^{-1}$ dose of covering $\mathrm{N}$, corresponds to the same amount that leads to $A E$ improvements (Farinelli \& Lemos, 2010).

As for physiological efficiency (PE), there were no significant differences among the cultivars, demonstrating that maize cultivars presented a compatible productivity with $\mathrm{N}$ accumulation, with a proper transformation of the nutrient into grain yield. A similar result was found by Carvalho et al. (2011a), who suggested that organic production was not a determinant factor to differentiate cultivars as for higher or lower $\mathrm{N}$ efficiency.

As for RE, the cultivar Cruzeta accumulated a greater amount of nutrient in the shoot per unit of applied nutrient. However it, did not differ from cultivar Truck, and this did not differ from cultivar AG 1051. This demonstrates that these cultivars were efficient in nutrient recovery, possibly minimizing losses of the element into the environment, and allowing a proper accumulation of $\mathrm{N}$ in the shoot.

As for UE, the cultivars did not present distinct behaviors regarding the use of $\mathrm{N}$. Carvalho et al. (2011b) also found no difference between the groups of evaluated cultivars, suggesting that the nutritional efficiency of a given cultivar does not depend on its genetic characteristics, and that the greater or less efficiency in $\mathrm{N}$ use by a particular maize cultivar will depend on the characteristics inherited from their genitors. According to DoVale et al. (2012), genitors contribute in a differentiated way to the transmission of alleles that control efficiency in the use of nitrogen. Sousa et al. (2018) verified that AG 1051 was more effective in using nitrogen to produce green ears as compared to Cruzeta and Truck.

\section{Conclusions}

Cultivars had higher productive performances when fertilized with nitrogen. Cultivar AG1051, based on the values on nutritional efficiency indices, was the most efficient in using nitrogen to produce grains, producing $14.40 \mathrm{~kg}$ of dry grains for each $\mathrm{kg}$ of applied $\mathrm{N}$.

\section{References}

ABIMILHO (2020) 6o Acompanhamento da Safra de Milho Total - 2019/20. Disponível em <http://www.abimilho.com.br/estatisticas/acompanhamento-da-safra> (Acesso em 10 abril 2020).

Andrade FR, Fabiano Petter FA, Nóbrega JCA, Pacheco LP, Zuffo AM (2014) Desempenho agronômico do milho a doses e épocas de aplicação de nitrogênio no Cerrado piauiense. Revista de Ciências Agrarias 57(4): 358-366.

Alvares CA, Stape JL, Sentelhas PC, Gonçalves JLM, Sparpvek G (2013) Köppen's climate classification map for Brazil. Meteorologische Zeitschrift 22(6): 711-728.

Caires EF, Milla F (2016) Adubação nitrogenada em cobertura para o cultivo de milho com alto potencial produtivo em sistema de plantio direto de longa duração. Bragantia 75(1): 87-95.

Cancellier LL, Afférri FS, Carvalho EV, Dotto MA, Leão FF (2011) Eficiência no uso de nitrogênio e correlação fenotípica em populações tropicais de milho no Tocantins. Revista Ciência Agronômica 42(1):139-148.

Carvalho RP, Von Pinho RG, Davide LMC (2011a) Desempenho de cultivares de milho quanto à eficiência de utilização de nitrogênio. Revista Brasileira de Milho e Sorgo 10(2): 108-120. 
Carvalho EV, Afférri FS, Peluzio JM, Leão FF, Cancellier LL, Dotto MA (2011b) Eficiência e uso do nitrogênio em híbridos experimentais de milho do programa de melhoramento da Universidade Federal do Tocantins. Bioscience Journal 27(3): 392-403.

Cavalcanti FJAC (2008) Recomendações de adubação para o Estado de Pernambuco. 2 $2^{\mathrm{a}}$ aproximação. Recife/IPA. 198 p.

CONAB (2020). Acompanhamento da safra brasileira de grãos safra 2019/20. Disponível em:<http://www.conab.gov.br> (Acesso em 10 abril 2020).

DoVale JC, Fritsche-Neto RF, Bermudez F, Miranda, GV (2012) Efeitos gênicos de caracteres associados à eficiência no uso de nitrogênio em milho. Pesquisa Agropecuária Brasileira 47(3): 385-392.

Fageria NK, Santos AB, Cutrim VA (2007) Produtividade de arroz irrigado e eficiência de uso do nitrogênio influenciadas pela fertilização nitrogenada. Pesquisa Agropecuária Brasileira 42(7): 1029-1034.

Farinelli R, Lemos, LB (2010) Produtividade e eficiência agronômica do milho em função da adubação nitrogenada e manejos do solo. Revista Brasileira de Milho e Sorgo 9(2): 135-146.

Ferreira DF (2014) Sisvar: A guide for its bootstrap procedures in multiple comparisons. Revista Ciência e Agrotecnologia. 38(2): 109-112.

Ferreira AO, Sá JCM, Briedis C, Figueiredo AG (2009) Desempenho de genótipos de milho cultivados com diferentes quantidades de palha de aveia-preta e doses de nitrogênio. Pesquisa Agropecuária Brasileira 44(2): 173-179.

Meira FA, Buzetti S, Andreotti M, Sá ME, Andrade JAC (2009) Fontes e épocas de aplicação do nitrogênio na cultura do milho irrigado. Semina, 30(2): 275-284.
Okumura RS, Mariano DC, Zaccheo PVC (2011) Uso de fertilizante nitrogenado na cultura do milho: uma revisão. Pesquisa Aplicada \& Agrotecnologia, 4(2): 65-71.

Oliveira FC, Sousa Netto M, Araújo LS, Almeida ACS, Silveira PM, Cunha PCR (2016) Corn development and production in function of sources of nitrogen fertilizers and doses. Revista Caatinga, 29(4): 812-821.

Rego LGS, Martins CM, Silva EF, Silva JJA, Lima RNS (2016) Pedogenesis and soil classification of an experimental farm in Mossoró, state of Rio Grande do Norte, Brazil. Revista Caatinga, 29(4): 1036-1042.

Santos WF, Silva RM, Sodré LF, Maciel LC, Aguiar RWS, Cangussu ASR, Santos MM (2017) Resposta e eficiência ao uso do nitrogênio em genótipos de milho tropicais. Tecnologia e Ciência Agropecuária, 11(4): 7-12.

Santos WF, Sodré LF, Pelúzio JM, Pereira JS, Reis IM, Silva RM (2018) Resposta e eficiência agronômica em genótipos de milho à adubação nitrogenada no Sul do Pará. Pesquisa Agropecuária Pernambucana, 24(02): 1-5.

Schiavinatti AF, Andreotti M, Benett CGS, Pariz CM, Lodo BN, Buzetti S (2011) Influência de fontes e modos de aplicação de nitrogênio nos componentes da produção e produtividade do milho irrigado no cerrado. Bragantia, 70(4): 925-930.

Soratto RP, Silva AH, Cardoso SM, Mendonça CG (2011) Doses e fontes alternativas de nitrogênio no milho sob plantio direto em solo arenoso. Ciência e Agrotecnologia, 35(1): 62-70.

Sousa CF, Grangeiro LC, Sousa VFL, Carneiro JV, Silva JLAS, Gomes LP (2018) Study of Nitrogen Efficiency of Three Corn Cultivars in Green Ears Production. Journal of Experimental Agriculture International 25(1):1-6. 